\section{Лiтература}

1. Концепція розвитку Тернопільського державного медичного університету імені І. Я. Горбачевського (інтеграція у світовий медичний освітній простір). - Тернопіль : ТДМУ, 2006.-50 с.

2. Медсестринська освіта в Університеті Південної Кароліни Апстейт (США) / за ред. чл.-кор. АМН України, д-ра мед. наук, проф. Л. Я. Ковальчука. - Тернопіль : ТДМУ, 2006. -397 c.

3. Досвід Віденського медичного університету в реформуванні системи освіти. Перспективи співпраці / за ред. чл.-кор. АМН України, д-ра мед. наук, проф. Л. Я. Ковальчука. - Тернопіль : ТДМУ, 2006. - 288 с.

4. Дворічна медсестринська освіта в США (за узагальненим досвідом штату Каліфорнія) / [Н. О. Ліщенко, О. С. Усинська, О. В. Шманько та ін.] . - Тернопіль : ТДМУ, 2006. -264 c.

5. Чехія: погляд на систему освіти / Л. С. Фіра, О. І. Острівка, О. Л. Сидоренко, П. Г. Лихацький. - Тернопіль : ТДМУ, 2006. - $100 \mathrm{c}$.
6. Андрейчин С. М. Медична освіта в Словацькій Республіці / С. М. Андрейчин, В. О. Качор. - Тернопіль : ТДМУ, 2006. -248 c.

7. Ковальчук Л. Я. Впровадження новітніх методик і систем навчального процесу в Тернопільському державному медичному університеті імені І. Я. Горбачевського / Л. Я. Ковальчук // Медична освіта. - 2009. -№ 2. - С. 10-14.

8. Ковальчук Л. Я. Новітні шляхи вдосконалення підготовки фахівців у Тернопільському державному медичному університеті імені І. Я. Горбачевського / Л. Я. Ковальчук // Медична освіта. - 2010. - № 2. - С. 27-30.

9. Методичні вказівки для викладачів щодо організації навчальногопроцесув ТДМУ.-Тернопіль: ТДМУ, 2007. - 86 c.

10. Стандарти і рекомендації щодо забезпечення якості освіти у Свропейському просторі вищої освіти. - К. : Ленвіт, 2006. - С. $15-16$.

11. Семестрові комплексні тестові іспити-надійний критерій оцінки знань студентів / I. Р. Мисула, В. П. Марценюк, К. О. Пашко, О. О. Стаханська//Медична освіта. -2010. -№ 1.C. $16-37$.

\title{
ПРОБЛЕМИ ОЩНЮВАННЯ ЗНАНЬ СТУДЕНТІВ У КОНТЕКСТІ ВИМОГ БОЛОНСЬКОЇ ДЕКЛАРАЦІї
}

\author{
І. С. Булах, О. П. Волосовець, М. Р. Мруга \\ Центр тестування, \\ Міністерство охорони здоров'я України
}

\section{DIFFICULTIES OF ASSESSMENT OF STUDENTS' KNOWLEDGE IN THE CONTEXT OF BOLOGNA DECLARATION REQUIREMENTS}

\author{
I. Ye. Bulakh, O. P. Volosovets, M. R. Mruha \\ Testing Board, \\ Ministry of Public Health of Ukraine
}

\begin{abstract}
Представлено ретроспективний огляд зміни системи оцінювання у вищих медичних навчальних закладах у контексті Болонської декларації.

There is presented retrospective overview of changes in assessment system in higher medical educational establishments in the context of Bologna process.

Вступ. Офіційне входження України в єдиний Європейський освітній простір через підписання Болонської декларації у 2005 році вимагало певної адаптації та перебудови різних аспектів організації навчального процесу у вищих медичних навчальних закладах

України. Зокрема, суттєвого реформування зазнала система оцінювання, зміни якої стосувалися як форми організації оцінювання знань і навчальної діяльності студентів, так і застосовуваних принципів оцінювання.
\end{abstract}


Основна частина.Принаймні чотири з десяти основних положень Болонського процесу прямо пов’язані 3 оцінюванням навчальних результатів студентів, що змушує вважати оцінювання одним із центральних компонентів реформи освіти в межах цього процесу [1]:

Прийняття системи зрозумілих і порівнянних ступенів

Запровадження системи кредитів

Забезпечення мобільності

Сприяння європейській співпраці в гарантуванні якості

Основні технічні вимоги до системи оцінювання викладені у системі ECTS (Свропейська система трансферу кредитів), що прийнята як уніфікована модель для Європейського освітнього простору. Важливо зазначити такі принципи ECTS, що вплинули на побудовунової системи оцінювання у вищій медичній освіті України:

- ECTS гарантує академічне визнання навчання, надаючи спосіб вимірювання та порівняння навчальних досягнень студента, і переведення його з однієї установи до іншої.

- Шкала ECTS розроблена як допомога закладам інтерпретувати бали, які студент отримав в інших закладах. Шкала містить інформацію, яка є додатковою до інформації у балах, та не замінюе місиеві икали.

- Шкала ЕCTS заснована на ранговому місиі студента серед інших студентів, щуо він отримав у результаті певного оцінювання.

- Система ЕCTS спочатку ділить студентів на групи “склав"/"не склав”, а потім оцінює результати циих двох груп окремо. Тих, хто “склав”, поділяють на n'ять підгруп: кращчі $10 \%$ отримують бал A, наступні $25 \%$ - бал B, наступні $30 \%$ бал $C$, наступні $25 \%$ - бал D i останні $10 \%$ бал Е. Тих, хто “не склав”, поділяють на дві nідгрупи: FX (Fail - студент повинен виконати невеликий обсяг роботи для зарахування кредиmy) та F (Fail - студент повинен виконати значний обсяг роботи для зарахування кредиту).

Основними вимогами до коректного використання шкали ECTS визначено наявність деталізованих первинних даних, що дозволяють адекватно диференціювати студентів за категоріями ECTS, достатній розмір вибірки студентів для валідного ранжування (не менше 30 осіб), застосування належних статистичних методів та забезпечення якості результатів, отриманих з використанням вказаної шкали [2]. На 2005 рік українська медична освіта здатна була задовольнити всі вимоги для коректного використання шкали ECTS, окрім наявності адекватних первинних даних, оскільки діюча в країні чотирибальна, а фактично трибальна, шкала не дозволяла справедливо диференціювати студентів за 5-ма групами ECTS.

Отже, грунтуючись на зазначених положеннях та вимогах до застосування системи ECTS, була розроблена система оцінювання, рекомендована українським медичним навчальним закладам з 2005-2006 н. p. Узагальнено можна вказати такі основні зміни в оцінюванні, що впроваджені у вищій медичній освіті:

1. Розширення впливу поточного оцінювання, тобто впливу щоденної праці студентів, на підсумковий результат.

2. Включення оцінювання у навчальне навантаження студентів, відмова від сесій та введення можливості декількох підсумкових оцінювань (підсумкових модульних контролей) для однієї дисципліни.

3. Широке використання об' єктивних методів оцінювання.

4. Введення структурованої оцінки з предмета і багатобальних шкал.

5. Одночасне використання абсолютного та відносного (рейтингового) принципів оцінювання для фіксації успішності навчання 3 конвертацією результатів за багатобальною шкалою в інші шкали $[3,4]$.

За період дії експериментального навчального плану деталі системи оцінювання обговорювалися та декілька разів переглядалися в процесі забезпечення якості, втім основні ії принципи залишалися незмінними протягом шести років.

Проблеми і переваги застосування інноваційної системи оцінювання у вищій медичній освіті. Найбільш суттєвий вплив на організацію навчального процесу на кафедрах, безумовно, мала вимога систематично оцінювати поточну діяльність та застосовувати більш об' єктивні методи контролю. На практиці це проявляється широким застосуванням тестування для поточного та підсумкового контролю на рівні окремих предметів ізбільшенням відносної ваги часу, що відводиться на оцінювання, у структурі загального навантаження студента. В перші роки оцінювання систематичної праці та використання надмірної кількості підсумкових модульних контролей для одного предмета призвело до збільшення кількості студентів-“боржників”. Утім ця проблема була врегульована у міру адаптації системи вищої медичної освіти до нових умов. 3 іншого боку, впровадження періодичного підсумкового контролю дозволяє закладам та студентам краще контролювати поступове опанування навчального плану. 
Використання багатобальної шкали дає можливість отримати детальніпервинні дані, придатні для ранжування студентів на 5 груп за шкалою ECTS. Використання структурованої оцінки з предмета дозволяє кафедрам “донести” до студентів ставлення кафедри до окремих видів їх роботи, наприклад, чим більше балів можна отримати за самостійну чи індивідуальну роботу, тим “ціннішим” є даний компонент для певної дисципліни.

Використання рейтингової оцінки для більшості навчальних закладів було абсолютно новим підходом. Можливо тому одночасне застосування абсолютних шкал (200-бальної шкали та національної шкали) та відносної шкали ECTS і конвертація результатів студентів між шкалами становили найбільшу проблему, що виносилась на публічне обговорення та досі вимагає дискусій, роз'яснень і додаткових консультацій. У 2011 році виник новий сплеск проблем з використанням рейтингового оцінювання за шкалою ECTS у зв'язку з необхідністю видачі Додатка до диплома (європейського зразка), який неповною мірою відповідає особливостям організації навчального процесу та оцінювання у медичних ВНЗ. Слід зазначити, що 3 аналогічними труднощами стикаються не лише вищі медичні навчальні заклади, а й ВНЗ інших профілів, де в перші роки експерименту з кредитно-модульної системи організації навчальногопроцесу за принципами Болонської декларації застосовували методично некоректну схему визначення груп ECTS, яка була покладена в основу національного Додатка до диплома (європейського зразка), що становить проблему для всіх ВНЗ, які здійснюють рейтингове оцінювання.

Висновок. Незважаючи на технічні труднощі із запровадження інноваційної системи оцінювання та окремі поточні недоліки, що корегуються в процесі постійного аналізу та забезпечення якості системи, можна вважати, що свої функції система оцінювання виконує, успішно підтримуючи реалізацію експериментального навчального плану за принципами Болонської декларації.

\section{Література}

1. Assessment matters. The quality assurance of student assessment in higher education. Report of an international working group. December 2008. - http://www.enqa.eu

2. http://en.wikipedia.org/wiki/ECTS grading scale

3. Про затвердження та введення нового навчального плану підготовки фахівців освітньо-кваліфікаційного рівня “Спеціаліст” кваліфікації “Лікар” у вищих навчальних зак-

ладах III-IV рівнів акредитації України за спеціальностями “Лікувальна справа”, "Педіатрія”, “Медико-профілактична справа”: наказ МОЗ від 31.01.2005 р. за № 52.

4. Медична освіта у світі та в Україні. Додипломна освіта. Післядипломна освіта. Безперервний професійний розвиток / [Ю. В. Поляченко, В. Г. Передерій, О. П. Волосовець та ін]. -К. : Книга Плюс, 2005. - 384 с. 